\title{
THE ROLE OF CLUSTERS IN MODERN GLOBAL ECONOMY
}

\author{
Valeriy Shiposha ${ }^{1}$
}

\begin{abstract}
The article deals with the role of clusters in today's global economy. It is noted that in today's economic environment it is difficult to overestimate the role of clusters in competition, which has changed significantly and continues to change due to the increased amount of information and knowledge about risk in the global economy. Considering the role of clusters in today's global economy, it is noted that in modern scientific literature there is no single and generally accepted definition of a cluster as such. Different scholars and economists understand and interpret this concept variously. M. Porter gives the most accurate definition of the cluster. The main characteristics of clusters are considered, namely: geographical concentration, specialization, multiplicity of economic agents. The goals for which clusters are usually directed are given, namely: increase of competitiveness of cluster participants due to introduction of new technologies; reducing costs and improving the efficiency of relevant high-tech services through the synergy effect and unification of approaches in logistics, engineering, information technology, quality management, etc.; providing employment in the context of largescale enterprise reforming and outsourcing; consolidated lobbying of the cluster members' interests in different authorities. The advantages of the cluster model for the development of the Ukrainian industry are considered and it is stated that among all the advantages of the cluster approach, the most important is the access to innovations, knowledge. It is stated that clusters can be formed in both traditional industries and high-tech areas, and very often different educational establishments or research structures serve as a specific center for cluster formation. It is concluded that within the state, clusters play the role of points of growth of the internal market and ensure the promotion of goods and services produced by them to international markets. This, in turn, contributes to the enhancement of the country's international competitiveness on the whole, due to a number of advantages inherent in the cluster form of interaction between large, medium and small enterprises in all areas of business relations. One of the directions of socio-economic development of Ukraine, to increase its competitiveness, should be the support and development of territorial production clusters.
\end{abstract}

Key words: cluster, global economy, competitiveness, goods, services, economy.

JEL Classification: C38, Q57

\section{Introduction}

Competitiveness in market conditions is one of the main categories that is actively employed in theory and practice. The global competitiveness of national economies increasingly depends on the efficiency of their internal organization and the degree of integration of internal regional subsystems. Nowadays, it is clustering that acts as a necessary form of internal integration and cooperation, which is able to ensure not only stability, but also the effect of counteracting the challenges of global competition from existing monopolies.

The idea of clusters as a means of ensuring the competitiveness of economic development of regions in recent decades has been developed worldwide.

Corresponding author:

${ }^{1}$ PHEI "International University of Business and Law", Ukraine.
The positive impact of clusters on the economic development of countries and regions of the world has led to the relevance of their role in the modern global economy.

Therefore, the study of the role of the cluster model of the economy is of great scientific and practical importance.

The role of clusters in modern global economy is studied by the following scientists: Zhyhalkevych Zh.M., Lizunov V.V., Nikolaev M.V., Okseniuk K.I., Porter M., Semenov H.A., Sobkevych O., Iukhimchik L., etc.

The purpose of the article is to research the role of clusters in the development of national and regional economies, which are components of the modern global economic space. 


\section{Presentation of the main research material}

Given the growing global challenges, which are primarily manifested in economic and financial instability of the world economic system, slowing its economic development, there is a question of finding new sources of economic development of such forms of international cooperation that will increase their sustainability and competitiveness in the global space. Clusters can act as these forms.

In modern economic environment, it is difficult to overestimate the role of clusters in competition, which has changed significantly and continues to change due to the increase in information and knowledge about the risks in the global economy.

It should be noted that due to clustering it is possible to form the necessary critical mass in various fields of activity, which, in turn, allows clusters to demonstrate the uniqueness and efficiency of any national, regional or territorial economy to the world.

It is important to mention the following: modern clusters are able to transform competition into integration cooperation without destroying competition as a strong driving force of the world economy. Also, the concept of the cluster is a new vision of the national economy, the economy of the region and the enterprise, and also points to the new roles of companies, governments and international organizations seeking to increase competitiveness in the global market.

Considering the role of clusters in the modern global economy, we note that in the modern scientific literature there is no single and generally accepted definition of the concept of cluster. Different scientists and economists understand and interpret it variously.

The most accurate definition of the cluster is given by M. Porter (Porter, 2005), according to which clusters are geographically concentrated groups of interdependent companies, specialized suppliers, service providers, firms in related industries, as well as organizations related to their activities (e.g. universities, standardization agencies, trade associations) in certain areas that compete, but work in the same field.

As for the main characteristics of clusters, the following are distinguished:

- geographical concentration (closely located firms give each other the opportunity to save on rapid economic interaction, capital exchange, etc.);
- specialization (clusters are concentrated around a certain area of activity to which all participants are related);

- multiplicity of economic agents (clusters and their activities cover not only the firms in the cluster) (Enhancing the Innovative Perfomance of Firms).

Clusters can be formed both in traditional industries and high-tech areas, and very often a kind of the center for the formation of clusters is various educational institutions or research structures. It is important that clusters are formed not only in a large but also small economy in both industrialized and developing countries. Interaction between cluster members can take the form from relatively simple, networked type of associations, to complex multilevel cooperative and competitive entities.

Tendencies to the formation of clusters often have a common scientific or production base, and the successful development of the cluster can be guaranteed only if the scientific base allows to build a cluster not on a specialized but on a differentiated type.

One of the important aspects of cluster policy is that the focus is on strengthening the networks of relationships between economic entities members of the cluster.

Thus, today the application of the cluster approach in Ukraine is a necessary condition for the revival of domestic production, increase the efficiency of innovative development of regions and achieve a high level of economic development and competitiveness.

It is worth agreeing with the position of V.V. Lizunov (Lizunov, 2008) that the viability of the cluster approach is also explained by its complex form and effective combination of industrial policy, regional policy, small business support policy, policy to attract foreign and domestic investment, innovative, scientific and technical, personnel, educational and other policies.

Nikolaev M.V. (Nikolaev, 2005) also notes that "the most important factor in the competitiveness of clusters is the high level of development of the system of related institutions and industries, and the public policy is performed for the formation of a national innovation system and the influx of qualified personnel".

Clusters are usually aimed at achieving the following purposes:

- increasing the competitiveness of cluster members through the introduction of new technologies; 
- reducing costs and increasing the efficiency of relevant knowledge-intensive services due to the effect of synergy and unification of approaches in logistics, engineering, information technology, quality management, etc.;

- providing employment in the context of reforming large enterprises and outsourcing;

- consolidated lobbying of the interests of cluster members in various authority bodies.

If we consider the role of clusters in the state, here they play the role of points of growth of the domestic market and ensure the promotion of their goods and services on international markets. This, in turn, contributes to accelerating the international competitiveness of the country as a whole due to a number of advantages inherent in the cluster form of interaction of large, medium and small enterprises in all areas of business relations.

The presence of clusters allows national industries to develop and maintain their competitive advantages without giving in to even the most technically developed countries. All companies in the cluster of interconnected industries invest in specialized research, in the development of related technologies, in information, in infrastructure development and human resources, which is manifested in a synergy effect and allows small businesses to withstand fierce competition in globalized markets.

As we noted above, the cluster approach is of particular importance for small businesses, and for some researchers (Zhyhalkevych, 2014; Nikolaev, 2005), the only way to save small firms in the context of globalization and growing international competition is seen in their clustering.

Let us consider the advantages of the cluster model for the development pf Ukrainian industry, which, in the opinion of O. Sobkevych (Semenov, 2006), are as follows:

- significant synergy effect, which will allow to involve resources of other sectors of the economy - education, science, financial sector, agriculture, defense, health, etc. in the development of the industrial sector due to the participation of these sectors in clusters;

- development of small and medium enterprises in industry through the development of outsourcing and subcontracting, which will help to deepen their cooperation with large industrial companies, deepen their specialization, develop niche production and expand access to financial resources for development;
- development of innovative directions in industrial production due to intensification of cooperation of industrial enterprises with research organizations, increase of innovative activity of small and medium enterprises in clusters. Due to the so-called "spillover" and closer contact with consumers and other companies, there are opportunities to create and disseminate new ideas and technologies among cluster members and beyond, which, in turn, contributes to the growth of value added and production orientation on manufacture of hightech end-use products (Okseniuk, 2012);

- development of innovation management in industry through the introduction of a new system of production and cooperation within the cluster, which will increase the quality and competitiveness of industrial products through a better understanding of the needs and requirements of suppliers and consumers to quality and technical characteristics of products and components, will lead to broken elements and significant time savings decrease.

- increase of the investment attractiveness of regions and the country as a whole, due to the higher level of investor confidence in developed network structures than in individual small companies, as well as guarantees and benefits to investors from the state if the latter participates in cluster initiatives (Iukhimchik, 2013);

- accelerating the pace of creation and development of new business. New companies have the opportunity to develop in more favorable conditions due to the establishment of relations with partners within the cluster;

- creation of a closed production cycle and value chain within the country through the identification and creation within the cluster of missing links in production, which contributes to the development of import substitution.

Considering the advantages of the cluster approach, we note that among all the advantages of the cluster approach, the most important is access to innovation, knowledge and know-how.

After all, in the knowledge-based economy, which is defined by knowledge-intensive traditional industries and emerging industries, companies are looking for their main competitive advantage in ideas and talented staff, which requires geographical proximity to skilled workers, best suppliers, consumer evaluators, highly skilled human resources, research and development tools, as well as industry leaders (Ukraina. Posluhy z pidtrymky MSP v priorytetnykh rehionakh). 
As industry expertise and know-how are accumulated and disseminated through businesses and innovative companies, the cluster approach is more likely to provide companies with information about technology benefits and changes in customer and consumer benefits.

\section{Conclusions}

Thus, we can conclude that clusters are the driving force of economic development, and they can be considered innovative systems of applied value, as scientific, technological and socioeconomic development requires the concentration of national resources.

The very clusters can be the impetus that, with the successful concentration of production, its specialization, the use of modern achievements of communication, coordination, cooperation and collaboration, will help to find growth points for each region, while ensuring its victory in competition.

Clustering for Ukraine is one of the ways to build an economy and support it at the appropriate level in the system of world economic relations, because through the restructuring of production it can coordinate all parts of the technological chain and attract large financial resources to increase competitiveness of regions, the state, and domestic and foreign investment, create new enterprises, promote innovative development.

Also, the presence of clusters helps to increase the exchange of information, the emergence of new producers from consumer industries (suppliers), from related industries or through separation.

Thus, one of the areas of socio-economic development of Ukraine, increasing its competitiveness, should be the support and development of territorial production clusters.

\section{References:}

Enhancing the Innovative Perfomance of Firms: Policy Options and Practical Instruments. United Nations. ECE/CECI. CR. 85 p.

Zhyhalkevych, Zh. M. (2014). Klastery vzaiemodiichykh pidpryiemstv ta ikh klasyfikatsiia [Clusters of cooperating enterprises and their classification]. Bulletin of ONU Mechnikov, vol. 2/3, pp. 98-101.

Lizunov, V. V. (2008). Klasternaia politika i perspektiva formirovaniia obrazovatelnykh klasterov [Cluster policy and prospects for the formation of educational clusters]. Omsk Trade and Economic Readings, vol. 2, pp. 484-498.

Nikolaev, M. V. (2005). Ekonomicheskaia globalizatciia i problemy natcionalnoi bezopasnosti [Economic globalization and problems of national security]. Problems of the modern economy, vol. 1(13), pp. 132-134. Okseniuk, K. I. (2012). Formyvannia ta rozvytok rehionalnykh innovatsiinykh clasteriv [Formation and development of regional innovation clusters]. Business Inform, vol. 9, p. 47-50.

Porter, M. (2005). Konkurentciia [Competition]. Williams Publishing House, 608 p.

Semenov, H. A. (2006). Klastery pidpryiemstv yak peredumova aktyvizatsii rozvytku rehionalnoi ekonomiky [Enterprise clusters as a prerequisite for activating regional economic development]. Economy and the state, vol. 4, pp. 11-13.

Sobkevych, O. (2012). Promyslova polituka yak chynnyk pisliakryzovoho vidnovlennia ekonomiky Ukrainy [Industrial policy as a factor of post-crisis recovery of the Ukrainian economy]. National Institute for Strategic Studies.

Ukraina. Posluhy z pidtrymky MSP v priorytetnykh rehionakh [Ukraine. SME Support Services in Priority Regions].

Iukhimchik, L. (2013). Tceli i zadachi formirovaniia i razvitiia regionalnogo innovatcionnogo klastera [Aims and tasks of formation and development of a regional innovation cluster]. International Agriculture Magazine, vol. 3, pp. 41-44. 